\title{
Comparative Constructions: An Introduction
}

\author{
Yvonne Treis \\ CNRS-LLACAN
}

\section{Preliminaries}

Comparison is a mental act by which two or more items are examined in order to assess similarities and differences between them. The comparison can be made with regard to a certain gradable, onedimensional property, and the items are then assigned a position on a predicative scale. This mental act of comparison finds its linguistic encoding in comparison constructions, especially comparative constructions for the expression of comparison of inequality or equative constructions for the expression of comparison of equality. The assessment that is made with regard to a multifaceted notion (e.g. manner) finds its linguistic correlate in similative constructions.

The linguistic literature has especially been concerned with comparison of inequality and comparative constructions, such as the English sentences in (1).

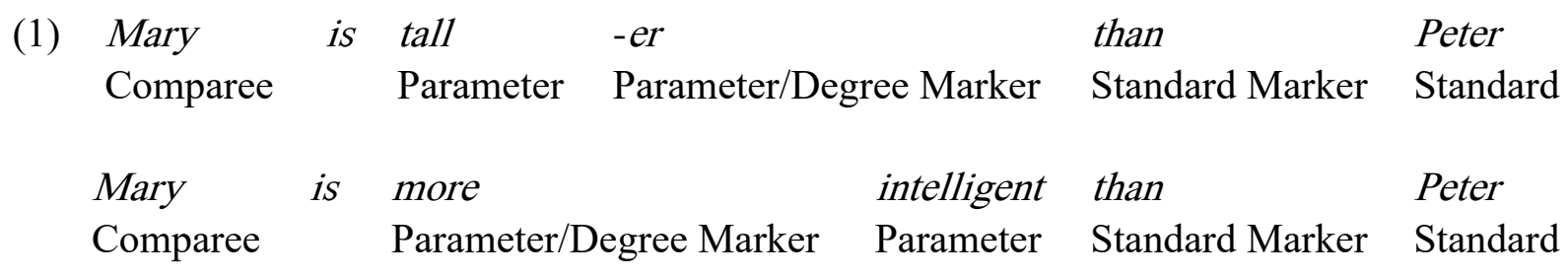

Comparative constructions are also the focus of this special issue, which evolved out of a two-day workshop titled "Comparative and Superlative Constructions: Typology and Diachrony" convened on 16-17 June 2015 at the Vrije Universiteit Amsterdam and organised by Lourens de Vries (Vrije Universiteit Amsterdam) and Katarzyna I. Wojtylak (James Cook University). The workshop aimed at taking a look at comparative constructions from a different angle - namely from the perspective of field linguistics. When attempting to analyse comparative constructions in a littleknown minority language, a fieldworker who has built up a multi-purpose corpus for a grammatical description of a language may, firstly, be confronted with difficulties in finding correlates to comparative constructions in other languages - often because the languages does not have dedicated, grammaticalized constructions for the expression of comparison. Speakers may use comparative strategies that rely on contextual implications of juxtaposed utterances (e.g. 'Mary is tall, Peter is not'). Secondly, rather than finding the one and primary comparative construction, descriptive linguists may come across a variety of comparative constructions, whose differences in meaning and use have to be teased out. Thirdly, comparative constructions in hitherto little known languages may challenge existing typologies. The workshop has been especially inspired by Dixon's (2012) work on comparative constructions.

The study of comparative and related constructions has a long and rich research tradition. There is a plethora of works on the expression of comparison in the languages of the world - studies on comparison constructions of individual languages, typological studies as well as formal-theoretical works (some of which are summarized in §3). This special issue on comparison could thus be said to stand on the shoulder of giants. After having laid out the terminology used in this special issue, I review a selection of typological works on comparison in Section 3. In Section 4 I present the questionnaire that has inspired the contributors to this volume to investigate the expression of comparison in their language(s) of expertise. In Section 5 I summarize what their studies can 
contribute to typological research on comparison constructions. In Section 6 all contributions to this volume are summarized.

\section{Terminology}

I have opted for the following terms to name the constitutive elements of a prototypical comparison construction, such as (1), in the contributions to this special issue. ${ }^{1}$ Note, however, the alternative terms found in the literature on comparison.

-COMPAREE = what is being compared against some standard of comparison (Mary); alternative terms used in the literature: ITEM COMPARED (Ultan 1972), TOPIC (Stolz \& Stolz 2001, Gorshenin 2012)

-STANDARD of comparison $=$ what the comparee is being compared against $($ Peter $)$

-STANDARD MARKER $=$ marker of the grammatical function of the STANDARD (than), alternative terms used in the literature: MARK (Dixon 2012), MARKER (Greenberg 1966), TIE (Stolz 2013), Pivot (Cuzzolin \& Lehmann 2004), RELATOR (Gorshenin 2012, Stolz \& Stolz 2001)

-PARAMETER of comparison = property of comparison (tall, intelligent); alternative terms used in the literature: QUALITY or QUANTITY (Ultan 1972), QUALITY (Stolz 2013), COMMENT (Gorshenin 2012, Stolz \& Stolz 2001), (COMPARATIVE) PREDICATE (Heine 1997, Stassen 1985, Stassen 2013)

-Degree MARker or PARAMeter MARKer marks the degree of presence or absence of a property in the comparee (more or -er); alternative terms used in the literature: INDEX (Dixon 2012), Degree (Stolz 2013, Gorshenin 2012, Stolz \& Stolz 2001), CoMPARATIVE CONCEPT (Heine 1994)

Of the five elements, standard markers and parameter/degree markers ${ }^{2}$ are often grammatical elements. Not all languages express all of the above constituents in comparison constructions. It is common for languages not to have a degree marker. Furthermore, as has already been pointed out in the literature (see e.g. Ultan (1972: 127)), it may be difficult to identify degree markers and standard markers in comparative constructions of certain languages. In languages of the 'exceed'comparative (see $\$ 3.1$ below), the degree and standard marking function is taken over by one structural element, the 'exceed' verb.

Most of the papers in this volume focus on comparative constructions in the narrow sense of the word, i.e. on constructions expressing inequality. However, the term "comparative" is potentially ambiguous and is also used in the literature as a general label for comparison constructions of all kinds. We have therefore opted to use "comparative" only in its narrow sense. For labelling other types of comparison we propose the terms discussed in the remainder of this section.

In traditional grammar, four degrees of comparison of the adjective are distinguished. The labels for these morphological forms of the adjective are also applied to the whole comparison

\footnotetext{
${ }^{1}$ If an author had a strong preference for other terms, their terminological equivalents were also mentioned.

${ }^{2}$ Parameter and degree marker are used interchangeably in this volume.
} 
construction in which they are used (see also Cuzzolin \& Lehmann 2004, Ultan 1972, Andersen 1983: 100).

-Positive degree: basic form of the adjective; Susan is tall $\rightarrow$ positive construction

-Equative degree: parameter is ascribed to the comparee and the standard to the same extent; Susan is as tall as Peter $\rightarrow$ equative construction

-Comparative degree: parameter applies to the comparee to a higher extent than to the standard; Susan is tall-er than Peter $\rightarrow$ comparative construction

-Superlative degree: shows the highest degree of the parameter applied to the comparee; Susan is the tallest of her family $\rightarrow$ superlative construction

Most contributions to this volume examine languages that do not mark degree morphologically on the adjective and, unsurprisingly, some of the languages discussed here do not even have an adjectival word class.

Inspired by Fuchs (2014), we subdivide and label the subtypes of comparison as follows: ${ }^{3}$

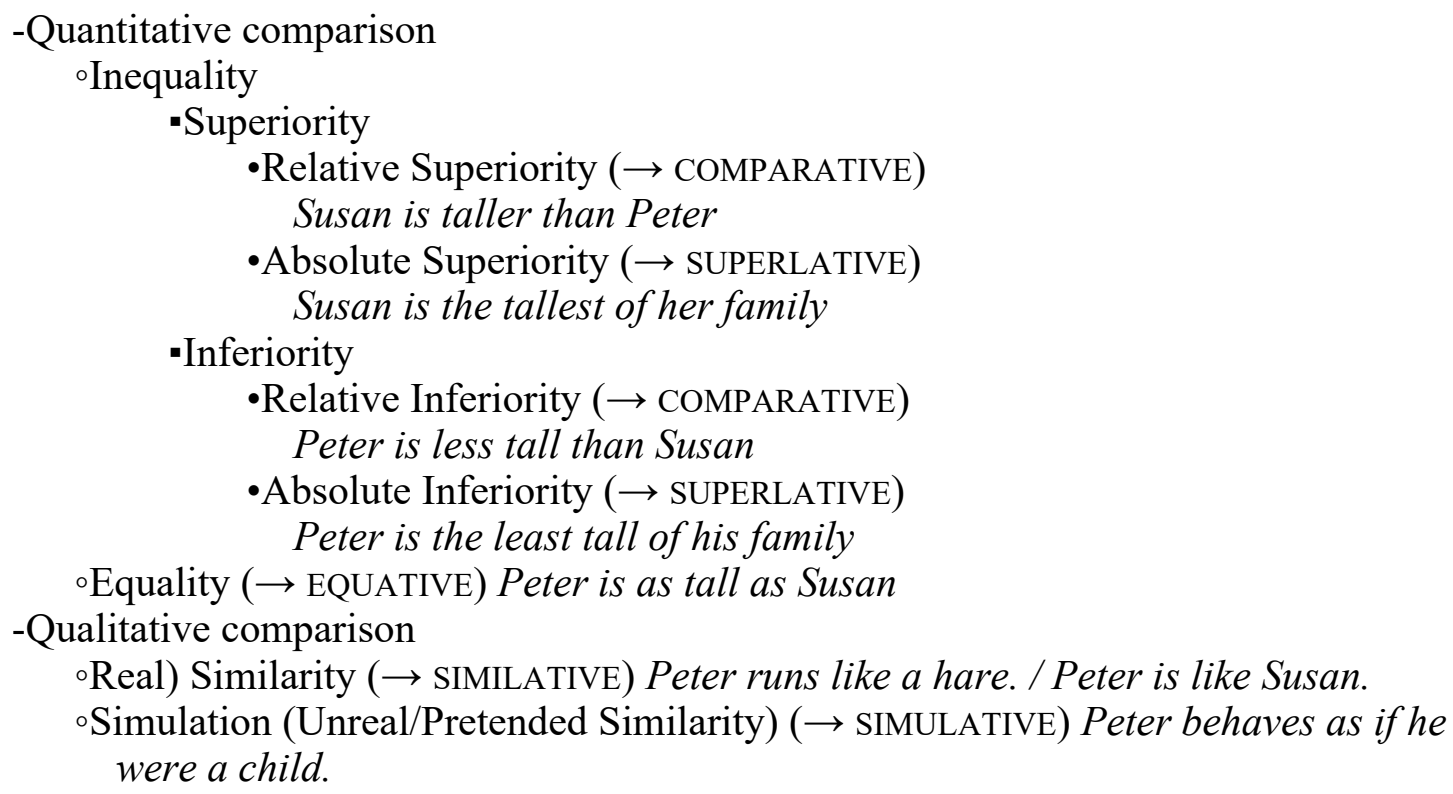

Several caveats apply to these terms:

The use of "absolute" above is different from the use of "absolute" in collocation with "superlatives" in other works on comparison. Ultan (1972:125), Gorshenin (2012: 82), Bobaljik (2012: 2) and Cuzzolin \& Lehmann (2004: 1213), for instance, distinguish between "relative superlatives" and "absolute superlatives", with the first type expressing "more [parameter] than all others' and the second type expressing an excessive degree, '[parameter] to a very high degree', e.g. a most interesting tale. "Absolute superlatives", in their sense, lack a specific standard of comparison. They are also called "elatives" in some traditions.

\footnotetext{
${ }^{3}$ Note, however, that Fuchs (2014) does not distinguish between relative and absolute inferiority and that she does not use the term "absolute" as I do here.
} 
The term "equative" used for a construction expressing equality should not be confused with the same term often used for a type of copular clause in which two entities are equated, e.g. Susan is our president. To avoid confusion, I suggest to use "equational" for this type of copular clause.

Finally, it needs to be pointed out that not all ambiguities regarding the term "comparative" have been resolved, as it can still be applied to constructions that express relative superior or inferior inequality.

\section{Literature Review}

Stolz (2013) provides a very detailed and informative review of earlier studies of comparative constructions to which I have little to add and which I encourage the reader to consult. In the following, I thus only summarize the comparative typologies by Stassen (1985) and Dixon (2012). Subsequently, the major works on superlative, equative and similative constructions are discussed in order to lay out the state of the art.

\subsection{Comparative}

The earliest cross-linguistic works on comparative constructions are Ziemer (1884) and Jensen (1934). Based on a world-wide sample of 123 languages, Ultan (1972) investigates universals in comparative, superlative and equative constructions worldwide. Most modern typologies of comparison constructions take Ultan's groundwork as a point of departure and review, test and refine hypotheses that he has brought forward.

Stassen's $(1985,2013)$ comparative types are predominately identified by the type of standard marker used. On the highest level, Stassen makes a distinction between derived-case comparatives and fixed-case comparatives, i.e. between constructions in which the case of the standard NP is dependent or independent on the case of the comparee NP. ${ }^{4}$ Fixed-case comparatives are then subdivided further according to the type of case form employed.

Fixed-case comparatives fall into Exceed Comparatives and Adverbial Comparatives (= Locational Comparatives in Stassen (2013)). In Exceed Comparatives (1985: 42ff, 159-82) a transitive verb meaning 'exceed', 'surpass' or similar takes the standard as its object and the comparee as its subject. In the first Exceed Comparative subtype, the parameter and the 'exceed' verb form one non-overtly marked serial verb construction ('A big exceed B'). In the second subtype, languages derank either the 'exceed' verb or the parameter and express it in a subordinate form; cf. the secondary comparative construction in Muna (4) discussed below. ${ }^{5}$

The mono-clausal Adverbial / Locational Comparatives encompass three subtypes. ${ }^{6}$ They all have in common that the standard NP is expressed by a phrase that is in an adverbial relation to the parameter. The three subtypes are based on three semantic models. The Separative Comparative (Stassen 1985: 114-35), which 30\% of the languages in Stassen's sample use as primary option, is characterized by a standard NP that is marked by a separative (source, origin) morpheme ('from', 'up from', 'beyond', 'behind', 'after'); see the ablative morpheme marking the standard in comparative constructions in Kambaata (2). Alaskan Athabascan comparatives (Tuttle

\footnotetext{
${ }^{4}$ Note that Stassen's "case" is to be understood in a very large sense of the word and could be paraphrased as "morphologically dependent or independent marker of grammatical function".

${ }^{5}$ Dixon (2012) splits up Stassen's Exceed Comparative into Type B and C.

${ }^{6}$ Stassen's Adverbial/Locational Comparatives would all be categorised as Type A1 or A2 in Dixon (2012). Bobaljik (2012: 22) joins up Stassen's Adverbial/Locational Comparative and Particle Comparative into Standard Comparative.
} 
this volume) marked by the postpositions nonte (Koyukon), yontha (Tanana) or yits'ae (Ahtna) 'beyond' would also categorize as Separative Comparative.

\section{(2) Kambaata (Afroasiatic, Cushitic)}
Bóq Makkeeb-éechch
qeráa'rr-u-a
PN.mNOM PN-fABL
long-mPRED-mCOP2
'Boqe is taller than Makkeebe (lit. Boqe is tall from Makkeebe).' (Treis this volume)

In Allative Comparatives (Stassen 1985: 40f, 136-45), the standard NP is marked like a goal ('to', 'up to', 'on this side of', 'in front of', 'before'). Comparatives in which the standard combines with a direct object or benefactive morpheme are also subsumed under this type.

Finally, Locative Comparatives (Stassen 1985: 41f, 146-52) mark the standard NP in an adverbial phrase with an element that indicates contact ('on', 'at', 'on top of', 'beside, next to', 'against'). As Wojtylak (this volume) shows, the Witotoan language Murui has a set of complex nominal standard markers, which all derived from locational adverbs, 'ahead', 'inside', 'above', 'below', 'outside', and are marked for a locative case.

\section{(3) Murui (Witotoan)

\begin{tabular}{|c|c|c|}
\hline $\mathrm{O}_{\mathrm{vcS}}$ & (eo) & jano-ñaiño ${ }_{\mathrm{vCC}}$ \\
\hline
\end{tabular} \\ 'She is smaller than I am (lit. she - very small (female), ahead of me).' (Wojtylak this volume)}

Derived-case comparatives are of two very different types. Conjoined Comparatives (Stassen 1985: 37f, 44f, 184-88) consist of two independent and structurally parallel clauses, one of which contains the comparee, while the other contains the standard. Comparee and standard have the same grammatical function in their respective clauses, and the parameter is expressed twice. The semantic relation between the clauses is one of adversative coordination: 'A is big, (but) B is small' or 'A is big, (but) B is not big'; cf. the discussion of comparatives in Ese Ejja and Turkish Sign Language below. ${ }^{8}$

The second derived case comparative is the mono-clausal Particle Comparative (1985: $38 \mathrm{f}$, 45ff, 188-98), in which the standard is accompanied by a comparative particle, which does not influence the case form for which the standard is marked; instead the standard derives its grammatical function from that of the comparee. The Particle Comparative is a fairly heterogeneous residual category in Stassen's typology; apart from being used as standard markers, the particles are used as 'and'-coordinators, as temporal adverbs ('then'), as adversative conjunctions ('but'), negative coordinators ('nor'), disjunctive coordinators ('or'), a similative

\footnotetext{
${ }^{7}$ Abbreviations: ABL ablative, ABS absolutive, ACC accusative, ADJ adjective, ANA anaphoric, C common gender, CL/CLF classifier, COP copula, D1 demonstrative (grade 1), DEM demonstrative, DEF/DF definiteness marker, ebr eyebrow raised, eo eye-opening, EQU equative, ERG ergative, EXS existential, f/F feminine, FACT factual/assumptive, GEN genitive, INT intensive, IX index, IX COMP index of comparison, LOC locative, $\mathrm{m} / \mathrm{M} / \mathrm{masc}$ masculine, NMLZ nominalizer, NOM nominative, NPF noun prefix, NREL negative relative, NUM numeral, OBJ object, OBL oblique, PFV perfective, PL plural, PN proper noun, POS positive, POSS possessive, PR pronominal, PRED predicative, PRES present, PRTV partitive, Q question, RDP reduplication, REAL realis, RLT relational, s/sg/SG singular, SGTV singulative, STD.M standard marker, SP specific, SU/SUBJ subject, SUP superlative, VIS visual

${ }^{8}$ The corresponding type in Dixon's (2012) typology (see below) is Type S.
} 
'like' or a relative/interrogative pronoun (cf. French que). Most languages with a Particle Comparative are members of the European sprachbund. ${ }^{9}$

This volume discusses several languages whose comparative constructions can only be tentatively categorized into Stassen's typology. The Austronesian language Muna (van den Berg this volume) marks the standard by a comitative morpheme bhe 'with' (4) - which is typologically fairly rare. Comitative marking is tentatively subsumed under Separative Comparatives in Stassen (1985: 37) but then not discussed any further. ${ }^{10}$

$\begin{array}{llll}\text { Muna (Austronesian) } & & \\ \text { No-tugha } & \text { kontu bhe wite } \\ \text { 3SG.SU.REAL-hard } & \text { stone } & \text { with land/soil }\end{array}$

'Stone is harder than soil.' (van den Berg this volume; glosses adapted)

The Ladakhi comparative (Zeisler this volume) could be classified - again only tentatively - as Particle Comparative. The standard marker -basay expresses a relation of difference or contrast and of 'beyond' or addition (see section 4 in Zeisler's contribution for details) and its multifunctionality is reminiscent of the standard markers of Particle Comparatives, as elaborated on in Stassen (1985: 188-98).

Note, however, that Muna and Ladakhi can easily be integrated into Dixon's typology, which is discussed further below.

Except for the Particle Comparative, all of Stassen's types find direct equivalents in Heine's Action, Source, Goal, Location and Polarity type (1997: 109-130). Heine proposes the following additional, though minor comparative types: Sequence (' $\mathrm{X}$ is $\mathrm{Y}$, then $\mathrm{Z}$ ' for ' $\mathrm{X}$ is $\mathrm{Y}$-er than $\mathrm{Z}$ '), Similarity (' $\mathrm{X}$ is $\mathrm{Y}$ like $Z$ ' for ' $\mathrm{X}$ is $\mathrm{Y}$-er than $\mathrm{Z}$ '), which replace Stassen's Particle Comparative, and Topic (' $\mathrm{X}$ and $\mathrm{Z}, \mathrm{X}$ is $\mathrm{Y}$ ' for ' $\mathrm{X}$ is $\mathrm{Y}$-er than $\mathrm{Z}$ '). ${ }^{11}$ The problems associated with establishing a (heterogeneous) type of Particle Comparative are discussed in Stolz (2013: 20ff). Along the lines of Heine, Stolz proposes to split up the Particle Comparative into several sub-types. In addition to Heine's Sequence and Similarity Comparative, Stolz introduces a Pure Comparative for constructions in which the standard is marked by a dedicated comparative case and a Contrastive Comparative for constructions in which the standard marker goes back to a negative or adversative morpheme (2013: 22). Topic Comparatives are said to be little attested (Stolz 2013: 13f, fn. 23) note, however, that in Turkish Sign Language (Özsoy \& Kaşıkara this volume) the two participants of Polarity and Location Comparatives are often first introduced as topics (5).

The descriptions of comparative constructions in this volume mostly refer to Dixon's (2008, 2012) typology. Unlike for Stassen and Heine, the etymology or multifunctionality of the standard marker in comparative constructions is of little relevance for the establishment of his types. Instead, the types are defined according to morphosyntactic parameters. Important features for the categorization seem to be (i) the mono-/bi-clausality of the construction, (ii) the syntactic functions of the primary components of a comparison scheme (parameter, comparee, standard, degree/parameter marker, standard marker), ${ }^{12}$ and (iii) the degree of grammaticalization of the

\footnotetext{
${ }^{9}$ This type would be covered by Dixon's (2012) Type A1 or A2, depending on the type of parameter used.

${ }^{10}$ See the discussion of the Nuer comparative with a comitative standard marker in Stolz (2013:20).

${ }^{11}$ Note that Heine (1997), strictly speaking, does not speak of comparative constructions but of event schemata, which are conceived of as the conceptual bases of comparative constructions of the languages of the world.

${ }^{12}$ Note that Dixon $(2008,2012)$ applies a different terminology for the semantic components of comparison expressions (cf. §2) and that his terms have been changed in the following summary if different from the ones used in this volume.
} 
construction. ${ }^{13}$ Compared to other typologies, Dixon gives more weight to non-canonical and little grammaticalized types - the eight main types are summarized in the following. ${ }^{14}$

Type A1 is a mono-clausal comparative construction, in which the parameter, expressed by an adjective (or noun) that functions as the head of a copula or verbless clause complement. If degree is expressed overtly, the degree marker is usually a modifier to the parameter. The standard is an oblique NP; the standard marker can be a dedicated morpheme or have other functions in the grammar (e.g. as ablative, locative, genitive morpheme) (Dixon 2012: 345-349). Type A2 differs from A1 only with respect to the word class of the parameter; here the parameter has verbal properties and functions as the head of an intransitive predicate (Dixon 2012: 349-353). Type A comparative constructions are attested in several languages of this volume; see, for instance, Kambaata (Treis), Muna (van den Berg), Murui (Wojtylak) (3) and Turkish Sign Language (Özsoy \& Kaşıkara) (5).

(5) Turkish Sign Language $\left[\left[\mathrm{NP} N\right.\right.$ IX $\left.\mathrm{X}_{\mathrm{a}}\right]$ [NP N IX $\left.\mathrm{I}\right]\left[\mathrm{a}_{\mathrm{I}} \mathrm{COMPb}\right.$ ADJ]

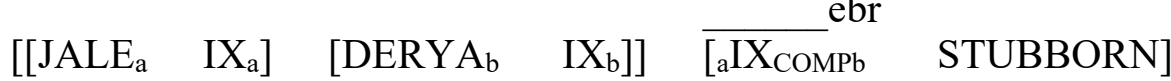 Jale SHE Derya SHE IX
'Derya is more stubborn than Jale.' (Özsoy \& Kaşıkara this volume)

Type B (Dixon 2012: 354ff) comparatives are serial verb constructions, in which a verb expressing the parameter and a verb 'exceed', '(sur)pass' or 'defeat' function together as a single predicate. The comparee is the transitive subject, the standard the object of the construction (lit. 'This girl pretty exceed that girl.'). No Type B comparatives are represented in this volume.

Type C (Dixon 2012: 356) differs from Type B in the syntactic function of the parameter. As in Type B, the 'exceed'-verb in $\mathrm{C}$ expresses the degree and takes comparee and standard as its arguments. The parameter, however, is expressed in a peripheral, post-predicate constituent. Type $\mathrm{C}$ is represented in this volume by the secondary 'exceed'-comparative in Muna (van den Berg this volume) (6) and the bi-clausal comparative constructions in Nivacle (Fabre this volume).

(6) Muna (Austronesian)

\begin{tabular}{|c|c|c|}
\hline Ina-ku & a-liu-e & ka-langke \\
\hline mother-1SG.POSS & 1SG.SU-surpass-3SG.OBJ & NMLZ-tall \\
\hline
\end{tabular}

In Type D (Dixon 2012: 357) the degree is also expressed by a transitive 'exceed'-verb. However, it takes the parameter as subject and object arguments; the comparee and the standard are the possessors in these argument NP (lit. 'The box's width exceeds the car's width'). No language in this volume is reported to have comparatives of Type D.

A particular type of comparative construction attested in Ponapean (Austronesian) makes Dixon (2012: 357f) establish Type E, which does not seem to correspond to any type in typologies by other authors. In Type E the parameter serves as the head of the predicate (as in Type A); the

\footnotetext{
13 The distinction between comparative "constructions" and "strategies" is not made in any other comparative typology.

${ }^{14}$ For information on two additional subtypes consult Dixon (2012: 349f and 353f).
} 
degree marker, however, is a (transitivizing) suffix to the parameter. The language is analysed as not having a standard marker. ${ }^{15}$ Note that a parallel equative type (with a transitivizing equative suffix) is attested in Ese Ejja (see $\$ 3.3$ below).

Dixon's Type F (2012: 358f) stands for bi-clausal comparative construction of three sub-types. In all sub-types, the parameter, the standard and the comparee are distributed across two clauses, e.g. as in Hua (Nuclear Trans New Guinea), where 'He is taller than me' is expressed literally as 'He exceeds me, he is tall'. For reasons not further elaborated on, Dixon distinguishes the biclausal Type F from the equally bi-clausal Type S (Dixon 2012: 359f), which is labelled a "comparative strategy". The examples of Type S comparatives all involve the juxtaposition of two (or more) complementary properties, e.g. ' $\mathrm{X}$ is big, $\mathrm{Y}$ is small'. A degree difference is usually not overtly encoded and has to be inferred from the juxtaposition of the contrastive clauses.

Dixon's Type S, which corresponds to Stassen's Conjoined Comparative, is represented in this volume by Ese Ejja and Turkish Sign Language. Vuillermet (this volume) discusses several types of bi-clausal comparatives, i.e. clauses forming antonymous pairs, positive-(lessened) negative pairs or (intensified) positive-'slightly' pairs (7). Özsoy \& Kaşıkara analyze several (sub-)types of bi-clausal comparatives in Turkish Sign Language. The antonymous subject comparative construction is exemplified in (8).

(7) Ese Ejja (Takanan)

$\begin{array}{clllll}\text { 'Beka } & \text { kia-kemo-nee nee } & \text { peyo } & \text { y-ani, } & \text { 'beka } & \text { iye-kemo } \\ \text { some } & \text { Pos-big-very RDP } & \text { snake } & \text { EXS-sit } & \text { some } & \text { SLIGHTLY-big }\end{array}$

'There exist some snakes that are bigger than others (lit. there sit some very big snakes, some not so big).' (Vuillermet this volume)

(8) Turkish Sign Language

[NP NUM N] [CL $\left.\mathrm{CL}_{\mathrm{a}} \mathrm{ADJ}_{1}\right]\left[\mathrm{CL}_{\mathrm{b}} \mathrm{ADJ}_{2}\right]$

$\left[\begin{array}{lllll}\text { TWO } & \text { MEN] [ONE TALL] [ONE } & \text { SHORT] }\end{array}\right.$

two men one man tall one man short

'(There are) two men. One is tall. One is short.' (Özsoy \& Kaşıkara this volume)

Three of the languages described in this volume constitute a major challenge for the existing comparative typologies. No type seems to fit the Nivacle 'all in one'-comparatives (Fabre this volume). In dedicated mono-clausal comparative constructions of this language, the parameter is a verb, the standard and comparee can be personal affixes to this verb, and the standard marker is a verbal suffix that goes back to an associated motion suffix.

(9) Nivacle (Mataguayo)

na-t'un- ${ }^{2}$ in-ji-k ${ }^{2}$ oja

2SUBJ-be.strong-INT-1-STD.M.THAN

'You (sg.) are much stronger than me.' (Fabre this volume; glosses adapted)

The categorization of Yalaku comparatives is equally difficult. As elaborated on by Aikhenvald (this volume), the language employs the directional verbs 'go up' and 'go down' for the expression of comparison. This is reminiscent of the use of 'surpass' verbs in Type B of Dixon's typology;

${ }^{15}$ Based on Dixon's analysis, a literal translation of this comparative Type E could be 'A biggers B'. 
however, the Yalaku comparatives juxtapose contrasting clauses and are in this respect similar to the strategies of Dixon's Type $\mathrm{S}$.

Yalaku (Ndu)
$\begin{array}{cllll}\text { [padi } & \text { tada- } d], & {[t u} & \text { wore- } d], & {[\text { semi- } d]} \\ \text { child } & \text { go.down-3MASC.SG } & \text { man } & \text { go.up-3MASC.SG } & \text { tall/long-3MASC.SG }\end{array}$

'The child is smaller than the father, (the father) is tall.' (lit. 'Child goes down, man goes up, (he) is tall.') (Aikhenvald this volume)

Finally, the categorization of the Japhug comparative construction (Jacques this volume; Jacques 2016) is unresolved. The postposed standard marker $s \gamma z$ 'than' is a dedicated comparative morpheme, and the construction could qualify as a Particle Comparative (or Pure Comparative in Stolz's (2013) terms). However, the comparee is marked by a postposed ergative/instrumental morpheme $\mathrm{km}$. The typological oddity of using the same marker for the A argument in a transitive clause and the comparee in an intransitive comparative construction and possible historical explanations are discussed in Jacques (2016).

\section{(11) Japhug (Tibeto-Burman)

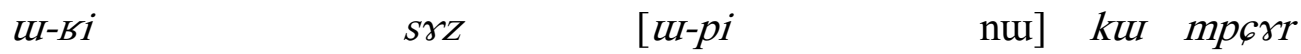 \\ 3SG.POSS-younger.sibling COMPARATIVE 3SG.POSS-elder.sibling DEM ERG be.beautiful:FACT \\ 'The elder one is more beautiful than the young one.' (Jacques this volume)}

The absence or presence of a degree marker on the parameter and its morphological status are not relevant for the establishment of types in Stassen's and Dixon's typologies. Degree marking is the central topic of Cuzzolin \& Lehmann's small paper (2004) on comparison and gradation, and it plays a major role in Bobaljik’s work on comparatives and superlatives (for details see §3.2). Cuzzolin \& Lehmann (2004) distinguish four comparative types based on the degree marking strategies: 1. no degree marker (as in conjoined comparatives), 2. optional lexical morpheme ('more', 'very'), 3. degree affix, 4. 'exceed' verb. Affixal degree marking is only attested in the comparative constructions of one (group of) languages in this volume, namely in Alaskan Athabascan (Tuttle). Some languages, e.g. Murui (Wojtylak) and Kambaata (Treis), can optionally use intensifiers ('very') in their comparative constructions. Turkish Sign Language (Özsoy \& Kaşıkara) has two degree marking options in locational comparatives; it either uses independent lexical signs or it incorporates the degree into the parameter sign. Muna (van den Berg), Nivacle (Fabre) and, possibly, Yalaku (Aikhenvald) fall into Cuzzolin \& Lehmann's Type 4.

While many languages, especially in Eurasia, have morphological means to express a superior degree (e.g. German -er as in klein-er 'smaller' and wichtig-er 'more important'), no language is known to mark inferior degree synthetically (see Bobaljik 2012: 209-213 and $\$ 3.2$ below). There are, however, languages that use parallel non-synthetic means for the expression of superiority and inferiority; see the degree adverbs plus 'more' and moins 'less' in French (12). 
(12)

$\begin{array}{llllllll}\begin{array}{l}\text { French } \\ \text { La }\end{array} & \begin{array}{l}\text { nouvelle } \\ \text { new.F }\end{array} & \begin{array}{l}\text { équipe } \\ \text { team }\end{array} & \begin{array}{l}\text { est } \\ \text { is }\end{array} & \begin{array}{l}\text { plus } \\ \text { more }\end{array} & \begin{array}{l}\text { forte } \\ \text { strong.F }\end{array} & \begin{array}{l}\text { que l'ancienne } \\ \text { than }\end{array} \\ \text { DEF.F_old.F } & \\ \text { La } & \text { nouvelle } & \begin{array}{l}\text { équipe } \\ \text { DEF.F }\end{array} & \text { newt } & \text { moins } & \text { forte } & \text { que } & \text { l'ancienne } \\ \text { team } & \text { is } & \text { less } & \text { strong.F } & \text { than } & \text { DEF.F_old.F }\end{array}$

'The new team is stronger / less strong than the old one.'

Furthermore, as reported by Dixon (2012: 362) with respect to the Chibchan language Teribe, the type of inequality relation between comparee and standard - superiority vs. inferiority - can also be encoded in the standard marker, with 'above' postposed to a superior standard and 'below' to an inferior standard. Languages with 'exceed' comparatives (Dixon's Type D) may have a parallel construction with a transitive verb 'fall short of'. Aikhenvald (this volume) shows how Yalaku makes use of the verbs 'go up' and 'go down' to indicate an increase or a decrease of a quality in comparatives of Type S.

Dixon (2012) discusses schemes of comparison that are rarely considered in grammatical descriptions or typological works, namely property comparison (John is more loyal than intelligent) and other complex comparatives as well as correlative comparatives (The riper the cheese, the stronger the smell) (2012: 367ff). This discussion has encouraged Jacques (this volume) to investigate property comparison in Japhug and van den Berg (this volume) to analyze correlatives comparatives in Muna.

There are indications that comparative constructions have a relatively high degree of borrowability and potential to diffuse. In linguistic areas traditionally poor in dedicated comparative constructions, dominant languages of wider communication may supply speakers of minority languages with grammatical models through calquing (Dixon 2012: 371, e.g. Malay, Turkish, English models). Areal patterns of the expression of inequality have been studied by Heine (1994) based on Stassen's (1985) word-wide sample and by Heine \& Zelealem (2003) with respect to Africa. The contact influence of Spanish on comparative constructions of various Amerindian and Austronesian languages is examined in Stolz \& Stolz (1995, 2001). Chamoreau (2012) investigates Spanish influence on comparatives in Purepecha (isolate, Mexico); Wojtylak (this volume) discusses how Spanish impacts comparative constructions in Murui (Witotoan). The most detailed areally oriented study of comparative constructions is Stolz (2013), which examines the coexistence of formally distinct morphosyntactic constructions for the expressions of comparison of inequality in European languages and the influence of language contact.

\subsection{Superlativity}

While the expression of relative inequality has been studied extensively, only few typological studies are dedicated to constructions of superlativity. Superlatives express that a comparee has a parameter to a higher degree than each individual entity in a group of (normally) more than two. In his 1972 publication on comparison, Ultan also discusses superlatives besides comparative and equatives. He notes the strong formal resemblances between comparatives and superlatives which are significantly more pronounced than those between comparatives and equatives. ${ }^{16}$ Frequently, standard markers and, if present, degree markers of comparatives and superlatives are the same or formally related; the parameters of comparatives and superlatives may have identical

\footnotetext{
${ }^{16}$ Superlatives are also briefly discussed in Heine (1994: 124ff, which is based on Ultan 1972), Cuzzolin \& Lehmann (2004) and Dixon (2012: 363ff).
} 
or similar suppletive forms (see good-better - best) or morphological patterns (see the so-called "elative" pattern in Arabic), and set comparatives and superlatives apart from equatives. ${ }^{17}$ Ultan's study is an important point of departure for the two most detailed typological studies on superlatives to date, Gorshenin (2012) and Bobaljik (2012). Both publications have occurred in the same year; the underlying studies have been carried out in parallel and apparently without knowledge of each other. Both authors have a very different take on the subject matter. Bobaljik is primarily an in-depth analysis of the morphology of degree marking. Gorshenin's working paper has a broader focus and develops a typology of superlative constructions according to (morpho-)syntactic features that differentiate superlatives from the constructions they are based on, i.e. comparative or simple positive constructions.

Gorshenin makes an important distinction between languages in which the superlative constructions are formally based on comparatives (and in which degree and standard markers are shared across these constructions) and languages in which superlative and comparative constructions are distinct (and in which degree or standard markers are not shared, and where superlativity is primarily expressed through a dedicated superlative degree morpheme) (2012: 79). ${ }^{18}$ Departing from a semantic definition of a superlative construction, Gorshenin classifies the construction types attested in the 55 languages of his sample, firstly, according to their primary (obligatory) superlative marker and, secondly, according to their derivational base (positive vs. comparative construction) (2012: 83). His classification results in five major types, which are named after the conceptual/semantic components that need to be explicit in the surface structure.

1. Type A = Absolute Comparison Superlative (Gorshenin 2012: 87-110): Type A is crosslinguistically the most common type ${ }^{19}$ It is based on a comparative construction with the standard expressed by a universal quantifier all, every(body/thing) or an indefinite pronoun any(body/thing) as head of the phrase or as modifier. Superlatives of Type A are hardly (if at all) grammaticalised. They can be based on any comparative type: adverbial comparatives (13), particle comparatives, 'exceed' comparatives, and (see Bobaljik 2012: 66) conjoined comparatives.

$$
\begin{aligned}
& \text { Khoekhoe (Central Khoisan) } \\
& \text { Ne khoi-b ge hoa-n xa a gei } \\
& \text { D1 person-3SG.M SUBJ all-3PL.C from COP.PRES big } \\
& \text { 'This man is bigger (taller) than anybody (or: is the biggest of all).' (Rust 1965: } 37 \text { cited } \\
& \text { after Gorshenin 2012: 88) }
\end{aligned}
$$

See also the Type A superlatives in languages discussed in this volume: Kambaata (Treis), Alaskan Athabascan (Tuttle), Ese Ejja (Vuillermet) and Murui (Wojtylak).

2. Type $\mathbf{S}=$ Scope Superlative (Gorshenin 2012: 111-122): Type $\mathrm{S}$ is characterised by the explicit expression of the scope, i.e. the group of entities that the comparee belongs to but from which it is singled out. It is either based on positive or comparative constructions. Languages with Type $\mathrm{S}$ superlatives mostly mark the scope-denoting noun by a locative adposition or affix; see the Kambaata Type $\mathrm{S}$ superlative in (14).

\footnotetext{
${ }^{17} 18$ out of 30 languages, for which Ultan has comparative, superlative and equative data, use the same standard marker in comparatives and superlatives (1972: 138).

${ }^{18}$ Note that Gorshenin applies a different terminology for the semantic components of comparison expressions (cf. $\S 2)$.

${ }^{19}$ This observation is confirmed by Ultan (1972: 123) and Bobaljik (2012: 89).
} 
Kambaata (Afroasiatic, Cushitic)

Haqq-áan färr-u m-áha-a-n?

wood-mLOC bad-mNOM what-mPRED-mCOP2-Q

'What is the worst wood(en thing) (lit. Among wood, the bad (one) is what?).' (Treis this volume)

The correct interpretation of Type $\mathrm{S}$ constructions presupposes (extra-linguistic) knowledge of the fact that the comparee is a member of the group identified by the standard (Gorshenin 2012: 115). In the same way as Type A, Type $\mathrm{S}$ is little, if at all grammaticalised. Furthermore, Type A and S reflect a common cognitive scheme, which the author summarizes in the formula [Topic is more Comment than $\mathrm{A}_{(1 \ldots \mathrm{n})}$ ] (2012: 160), or according to the terminology of this volume: [Comparee is more Parameter than $A_{(1 \ldots n)}$. A superlative expresses multiple comparison of a comparee with all entities belonging to the scope. The scope is either expressed by a universal quantifier or the group to which the comparee belongs is named.

3. Type DEG = Conventionalized Degree Superlative (Gorshenin 2012: 122-143): Type DEG is characterised by the obligatory use of a dedicated degree marker, which accompanies the parameter and can either be free or bound; cf. e.g. English -est as in great-est and most as in most important. The superlative morpheme -en in Basque (15) contrasts with the comparative degree marker $-a g o .{ }^{20}$ For a free superlative degree marker see also Japhug (Jacques this volume).

Basque (isolate)

\begin{tabular}{|c|c|c|}
\hline & $\begin{array}{l}d-a \\
3 \text { ABS-COP PRES }\end{array}$ & $\begin{array}{l}\text { eskola-ko } \\
\text { school-RLT }\end{array}$ \\
\hline
\end{tabular}

'Miren is the most beautiful among the girls of the school.' (Saltarelli 1988: 128, 249, cited after Gorshenin 2012: 128)

Most languages of Gorshenin's sample add the superlative morpheme to the positive form of the adjective. Note, however, that Hungarian prefixes the superlative to the comparative form, e.g. leg-magas-abb SUP-tall-COMP 'tallest' (2012: 133), and that Yaitepec Chatino adds the superlative after the comparative particle (2012: 139).

4. Type INT = Intensifier Superlative (Gorshenin 2012: 143-149): Type INT includes an overt degree marker, which is, however, not restricted to the expression of superlativity but has a general intensifying function 'very', 'by far', etc. (16). Depending on the language, the intensifier is added to the comparative or the simple positive predication.

(16) Ese Ejja (Takanan)

Jikio 'beka e-sowi kia-pame-nee nee

DEM some NPF-story POS-good-very RDP

'There is no other commandment greater than these (lit. these few words are very very good).' (Vuillermet this volume)

The following cognitive schema is said to underlie the morphosyntactically defined types DEG and INT: [Topic is especially Comment], or in the terminology of this volume: [Comparee is

${ }^{20}$ For Bobaljik (2012: 116-120) it is unclear whether Basque -en is a true superlative suffix. 
especially Parameter] (Gorshenin 2012: 160). The comparee has a salient, intensive quality, which is either expressed by a dedicated superlative morpheme (DEG) or elative morpheme or lexeme (INT).

5. Topic (= Comparee) Prominence Superlatives fall into two subtypes. Type DEF superlatives (Gorshenin 2012: 149-152) are characterised by the obligatory occurrence of a definiteness morpheme in the predicative constituent (17).

$$
\begin{aligned}
& \text { French } \\
& \text { Paul est le plus intelligent } \\
& \text { PN COP.3SG.PRES DEF.SG.M COMP intelligent } \\
& \text { 'Paul is the most intelligent.' (Gorshenin 2012: 150; glosses adapted) }
\end{aligned}
$$

In the second subtype, Type FOCUS, the comparee is singled out in a focus construction (lit. 'It is A which is tall' for 'A is the tallest') (Gorshenin 2012: 152f). Both subtypes reflect the cognitive scheme [Topic is salient with respect to Comment], or said differently: [Comparee is salient with respect to Parameter] (2012: 160).

Regarding the determining internal factors for the choice of a certain superlative strategy, Gorshenin points out that "the way a language expresses the Degree component in its comparative predications is much more relevant for its choice of a particular superlative type than the way in which the Relator [= standard marker] is expressed." (2012: 161). Regarding external factors, Gorshenin emphasizes, like Bobaljik (2012), the importance of areal factors for the choice of certain superlative strategies (2012: 164-168). Type A Superlatives are common in the world except in Europe. Languages of Africa and America prefer periphrastic/non-grammaticalised ways of expressing superlativity, i.e. Type A + Type S. Among languages having Type DEG constructions, almost three fourths are spoken in Eurasia; synthetic superlatives are almost exclusive to Eurasia. Finally, Type DEF Superlatives are concentrated around the Mediterranean.

Based on a much larger survey of 300 languages, Bobaljik (2012) examines recurring crosslinguistic regularities of comparative and superlative suppletion. In many languages, a handful of adjectives base their comparative form on a root that is not related to the root used for the positive, see, for instance, English good - better - best (pattern ABB) and Latin bonus - melior - optimus ' $g o o d '(A B C)$. When an adjective is marked for degree by suppletion, then it is suppletive in both the comparative and superlative grade (2012: 27-31). ${ }^{21}$ In the majority of cases, comparative and superlative forms use the same suppletive root; suppletive triplets as in Latin are crosslinguistically rare (2012: 29). Virtually unattested are cases in which an adjective in a language has only a suppletive comparative (hypothetical pattern: *ABA) or only a suppletive superlative (*AAB). Bobaljik counts about one hundred distinct cognate suppletive triplets in the languages of his sample (2012: 111-112). The most common suppletive qualitative roots mean 'good' and 'bad'; the most common suppletive quantifiers are 'many/much' and 'few, little' (2012: 128f), e.g. German viel - mehr - (am) meisten 'much' and Latin paucus - min-or - min-imus 'few'.

Bobaljik draws other important generalizations from his data: No language has morphological (synthetic) superlatives (A-est) but only periphrastic (analytic) comparatives (more A); ${ }^{22}$ and if a language has suppletive degree forms, they are limited to morphological (synthetic) comparatives, i.e. suppletive roots are not used in analytic comparatives (hypothetical *more bett for better

\footnotetext{
${ }^{21}$ Bobaljik (2012: 171) also formulates the following tentative generalization: "If the comparative degree of an adjective is suppletive, then the corresponding change-of-state verb is also suppletive (i.e., with respect to the positive adjective)." - See e.g. German gut / bess-er / (am) be-sten 'good' and ver-bess-ern 'improve'.

${ }^{22}$ See, however, the Tagalog and Hiligaynon examples in Gorshenin (2012: 130f).
} 
(2012: 70). The strongest empirically supported generalization concerns the expression of inferiority: Unlike comparison of superiority, comparison of inferiority is never affixal in languages (2012: 209-213).

\begin{tabular}{|l|l|l|}
\hline & analytic & synthetic \\
\hline superiority & more ADJ & ADJ-er \\
\hline interiority & less ADJ & $*$ \\
\hline
\end{tabular}

(Bobaljik 2012: 210)

Bobaljik finds morphological marking of comparative and superlative degree around the globe, but comparative and superlative suppletion remains an areal phenomenon. Suppletive marking is limited to about 70 European languages and its close neighbours, i.e. Indo-European, Finno-Ugric, Kartvelian, Northwest Caucasian and Basque (2012: 17, 41f).

Given the different foci and theoretical backgrounds, Gorshenin's and Bobaljik's works complement each other. They seem to disagree, however, in one important aspect of their analysis. Embedded in the framework of Distributed Morphology, Bobaljik states in his most central hypothesis that " $[\mathrm{t}]$ he representation of the superlative properly contains that of the comparative [in all languages that have a morphological superlative]" [Containment Hypothesis] (Bobaljik 2012: 73). The embedding of the superlative in the comparative is shown to be transparent in the overt synchronic (or diachronically reconstructable) morphology in many languages, in which a superlative morpheme consists of a comparative morpheme and a superlative morpheme proper. Additional important evidence comes from shared suppletive comparative-suppletive patterns. ${ }^{23}$ The universal claim that superlatives always contain comparatives is even maintained when this relation is not morphologically transparent, i.e. seen on the surface (Bobaljik 2012: 108). In contrast, Gorshenin emphasizes that, although superlatives can be assumed to be a semantic subtype of comparatives, not all superlative constructions are formally based on comparative constructions - see his prominent distinction between positive and comparative derivational bases (2012: 78, 80).

The information on the distribution of superlative types in Gorshenin's and Bobaljik's works has been assembled in a database and visualized on an interactive map by Coppock (2016).

The languages in this volume all lack morphological superlative marking on adjectives or other property words. Only Japhug, a Tibeto-Burman language (Jacques this volume), has a dedicated free superlative degree morpheme and is hence the only language of this volume that can be said to have grammaticalized superlativity. The contributions assembled here provide additional evidence for Gorshenin's and Bobaljik's observation that superlativity is infrequently grammaticalized in the languages of the world.

\subsection{Equality}

Comparison of equality has been studied in a cross-linguistic perspective by Haspelmath \& Buchholz (1998), based on a sample of European languages, Henkelmann (2006) on 25 languages worldwide, and Haspelmath et al. (2017) on 119 languages worldwide. Equatives are contrasted to comparatives in Ultan (1972); equative degree marking is also briefly discussed in Cuzzolin \& Lehmann (2004) and Dixon (2012: 361f).

\footnotetext{
${ }^{23}$ The derivation of superlatives from comparatives is also said to be evident in many languages with periphrastic superlatives (Bobaljik 2012: 77).
} 
Haspelmath et al. (2017: 14f, 18-22) divide the equative constructions into six primary types with reference to the five core components of comparison constructions (cf. $\S 2$ ). The six primary types differ in whether equative degree is overtly expressed or not, whether the notion of equality is expressed in a primary predicate (with the parameter backgrounded) or in a secondary predicate (with the parameter foregrounded), and whether comparee and standard are encoded in separate phrases or in one unified phrase. Unlike in many typologies of comparative constructions, the etymology and/or multifunctionality of the standard marker is not considered relevant for the establishment of types. Likewise, the morphological status of standard and degree markers is not decisive for their categorisation.

-Type 1: Only equative standard marker - "Kim is tall [like] Pat]."

-Type 2: Equative degree-marker and standard-marker - "Kim is [equally tall] [as Pat]."

-Type 3: Equative degree-marker unified - "[Kim and Pat] are [equally tall]."

-Type 4: Primary reach equative - "Kim [reaches/equals Pat] in height."

-Type 5: Primary reach equative unified - "[Kim and Pat $]$ are equal (to each other) in height."

-Type 6: Secondary reach equative - "Kim is tall [reaching/equaling Pat]."

Type 1, which lacks a degree marker, is the most common type in Haspelmath et al.'s (2017) sample and also represented in this volume; see (18) from Ladakhi, where the standard is marked by the suffix -tsek, while the parameter is not marked for degree.

Ladakhi, Shamskat dialects, Domkhar variety (Western Tibetan, Tibeto-Burman)

$\begin{array}{llll}\text { Itfanma }+O & \text { nay-po-tsek } & \text { thonbo } & \text { duk } \\ \text { tree.DF } & \text { house-DF-as.much } & \text { high } & \text { VIS.be }\end{array}$

'The tree is as high as the house (visual evidence).' (Zeisler this volume)

The morphological status of the standard marker can, of course, vary from language to language; in Murui (Wojtylak this volume) and Alaskan Athabascan (Tuttle this volume), for instance, the equative standard markers are postpositions rather than suffixes. In some languages of the world, the equative standard marker is a special case morpheme; see, for instance, the equative case in Ancash Quechua (Cuzzolin \& Lehmann 2004: 1219, Haspelmath \& Buchholz 1998: 285) and Siberian Yupik (de Reuse 1994: 34, cited after Schulze 2017).

Type 1 is represented in this volume by Ladakhi (Zeisler), Kambaata (Treis) and Murui (Wojtylak).

Type 2 is very common in Europe. The so-called "correlative constructions", a subtype of Type 2, is characteristic of the European Linguistic Area, but not attested outside of Europe (Haspelmath et al. 2017: 19). In these particular constructions, a demonstrative (see tam in (19)) is used as degree marker and a formally related adverbial relative morpheme 'how' (quam in (19)) as standard marker.

Latin (Romance, Indo-European)
Claudia tam docta est quam Julius
Claudia [so learned] is

'Claudia is as learned as Julius.' (Haspelmath et al. 2017: 12) 
Even though correlative constructions are not found outside of Europe, one also finds on other continents languages that use both a degree and a standard marker in their equative constructions. It is no clear whether Type 2 is represented in our volume. The only possible representative seems Alaskan Athabascan (Tuttle); note, however, that the degree marker $d$ - used in equative constructions is also used in comparative constructions.

In the languages of the world, analytic is more common than synthetic equative degree marking. In Europe, synthetic equative degree marking is restricted to Celtic, Finno-Ugric and Kartvelian languages. Synthetic equative degree marking is also attested in some non-European languages, such as Indonesian, Tagalog and Greenlandic Eskimo (Cuzzolin \& Lehmann 2004: 1218; Haspelmath \& Buchholz 1998: 283). Apart from Alaskan Athabascan, this special issue includes another language with synthetic equative degree marking, namely Ese Ejja (Vuillermet). This language does, however, not qualify as a Type 2 language for reasons elaborated below.

In Type 3, the comparee and the standard are conjoined in a noun phrase. In Type 4, which is common in African languages, equality is expressed by a verb meaning 'equal, reach'. In general, the verb is transitive and takes the comparee as subject and the standard as object. One of the equative constructions of the Tibeto-Burman language Japhug (Jacques this volume) might also classify as Type 4, as it is a serial verb construction of a similative verb 'be like', which takes the comparee and the standard as arguments, as V1 and a quality verb as V2. ${ }^{24}$

In Type 5, comparee and standard are conjoined in a noun phrase with 'equal, reach' as the main predicate. In this special issue, Type 5 is represented by the second equative construction of Japhug (Jacques). Finally, in Type 6, the parameter is the primary predicate, while equality is expressed in a secondary predicate.

Haspelmath et al. (2017: 25) have found little evidence for languages that have only degreemarkers but no standard markers in their equative constructions ("Kim is [equally tall] Pat"), but the description by Vuillermet (this volume) shows that Ese Ejja could be a language with such a equative construction type. In (20), the adjectival parameter 'big' is marked for equative degree by a morpheme -jja, which enables the adjective to take a second (incorporated) semantic argument. The Ese Ejja example is very reminiscent of the only potential counterexample presented by Haspelmath et al. (2017: 25), cited after Olawsky (2006). In Urarina, a handful of adjectives receive a transitivizing equative degree suffix and can then combine with an unmarked preposed standard. ${ }^{25}$

$$
\begin{aligned}
& \text { Ese Ejja (Takanan) } \\
& \text { 'Bawapoji Miguel-kemo-jja } \\
& \text { Alejandro Miguel-big-EQU } \\
& \text { 'Alejandro is as tall as Miguel.' (Vuillermet this volume) }
\end{aligned}
$$

After a discussion of the primary types, Haspelmath et al. (2017: 23f) also mention some infrequently attested other types in their data (see also Henkelmann 2006), among these minor types are conjoined (biclausal) equatives ("Kim is tall, Pat is like that, too") ${ }^{26}$ and equatives in which nominalized parameters are the primary arguments ("Kim's tallness is like Pat's tallness"). One of the Nivacle equative constructions could qualify as a biclausal equative (see construction 6 in Fabre's description). Equative constructions in Muna, an Austronesian language described by van den Berg in this volume, resemble the second minor type of Haspelmath et al.'s. But while the

\footnotetext{
${ }^{24}$ Note, however, that Jacques sees similarities between this construction and Haspelmath's Type 1.

${ }^{25}$ Cuzzolin \& Lehmann (2004: 1219) also cite an Indonesian example which seems to be of this unattested type.

${ }^{26}$ See also the equative example from Pilagá (Guaykuruan) cited in Dixon (2012: 358, ex. 30).
} 
parameter is nominalized in Muna equative constructions, the comparee and standard are conjoined.

(21) Muna (Austronesian)

Sau aini bhe sau aitu no-pototo ka-wana-no

wood this with wood that 3SG.SU.REAL-same NMLZ-long-3SG.POSS

'This piece of wood and that piece of wood (near you) are equally long.' (Lit. '... its

length is the same.') (van den Berg this volume; glosses adapted)

To summarize, some equative constructions discussed in this special issue can easily be categorised into one of the types proposed by Haspelmath et al. (2017), but for many constructions it is difficult, if not impossible to decide to which type to associate them. The primary Muna equative construction (van den Berg) resembles one of the proposed minor types, Ese Ejja (Vuillermet) seems to be an example of an unattested type, the various Japhug constructions (Jacques) are only remotely similar to the established types. Finally, one of the Nivacle equative constructions, the "all-in-one equative" (construction 5 in Fabre's paper), defies categorization, too. Given that all descriptions are primarily based on fieldwork corpora, some of which contain only few equative examples, the question of how generalized attested expressions of equality are (a problem that is also addressed in Haspelmath et al. 2017) must remain open in many cases.

\subsection{Similarity}

Expressions of similarity, a comparison with regard to the manner in which actions are carried out, are usually not included into typological works on the expression of comparison. ${ }^{27}$ A notable exception is Haspelmath \& Buchholz (1998), based on data from 43 European languages. In their contrastive study of equative and similative constructions, they show that in the majority of Standard Average European languages the standard marker in equative and similative constructions is identical or formally related, notable exceptions are English (as vs. like), three Roman languages including French (que vs. come), and nine non-SAE languages (1998: 313ff). English is thus a fairly exceptional SAE language making a formal distinction between equative and similative constructions (22)-(23); note especially the use of as [2] vs. like has standard marker.

(22) English (Haspelmath \& Buchholz 1998: 278)

Robert is as [1] tall as [2] Maria

\section{(23) He sings like a nightingale}

The use of one and the same standard marker in both types of comparison constructions seems common all over the world (a large-scale typological study has yet to be carried out). If equative degree is not marked overtly in a language (unlike in English where as [1] is used), and if no formal distinction is made between lexemes expressing properties and action/processes (unlike in English where the adjectival predicate is tall is formally different from a verbal predicate sings), then equative and similative constructions don't display any formal differences at all.

\footnotetext{
${ }^{27}$ Recall, however, that Fuchs (2014) in her work on comparison in French discusses inequality, equality as well as similarity.
} 
Formal resemblances between equative and similative constructions are also observed in the languages discussed in this volume. In Kambaata, for instance, the enclitic morpheme $=g$, which goes back to a noun meaning 'manner', marks standards of equative (24) and similative constructions (25).

$$
\begin{aligned}
& \text { Kambaata (Cushitic, Afroasiatic) } \\
& \text { Zoobb-ée }=g \text {-a } \quad \text { xalig-á } \quad i k \text {-kumbóochch }(. . .) \\
& \text { lions-mGEN=G-mOBL/ACC strong-mACC be-2sNREL.ABL } \\
& \text { 'Unless you are strong like/as strong as lions, (...).' (Treis this volume) } \\
& \begin{array}{lll}
\{\text { Adan-ch-ó }=\boldsymbol{g} \text { - } a\} & \text { gá'l-a } & \text { agg-óomm } \\
\text { cats-SGTV-mGEN=G-mACC/OBL } & \text { shard-mOBL } & \text { drink-1sPFV }
\end{array}
\end{aligned}
$$

In Japhug (Jacques this volume), the first of three equative construction is analyzed as a particular type of the similative serial verb construction; both constructions include the verb 'be like'. In Alaskan Athabascan (Tuttle this volume), the equative standard marker is glossed as 'like' - which could imply that this morpheme is also used for the expression of similarity. In Murui (Wojtylak this volume) and Ese Ejja (Vuillermet this volume) there are possibly etymological links between the grammatical morphemes used in similative and equative constructions. With respect to Nivacle, Fabre (this volume) states explicitly that " $[\mathrm{t}]$ here is no clear-cut morphosyntactic distinction between equatives and similatives". Many contributions to Treis \& Vanhove (2017) that compare the encoding of equality and similarity in individual languages also note straightforward formal connections between equative and similative constructions. ${ }^{28}$

\section{Questionnaire}

The following analytical questionnaire has been shared with the contributors to this volume as an aid to examine comparison constructions from various angles. The questionnaire has been inspired by but is not congruent with Dixon's questionnaire (2012: 372f), which the reader is also encouraged to consult.

\section{Part 1}

-Is there a dedicated comparative construction? If so, what is its typological type(s) in the various well-known typologies (e.g. Stassen 1985, Heine 1997, Dixon 2012)? If not, does the language have other periphrastic means of expressing comparison (so-called "comparative strategies" in Dixon 2012: 359f)?

-If there are several means/constructions for expressing comparison of inequality (e.g. several constructions expression superiority), what are the semantic, pragmatic or morphosyntactic factors conditioning their use? Are there differences in frequency?

-What is the form and structure of the constitutive elements of the comparative construction?

\footnotetext{
${ }^{28}$ During the compilation of their equative database, Haspelmath et al. (2017: 13) observed that "[e]quative standard markers are often glossed with 'like' by language describers, suggesting that the marker could also be used for similarity of manner".
} 
-What is the grammatical status of the PARAMETER of comparison (e.g. adjective, stative verb, verb)? Does the PARAMETER belong to a closed word class? Is the PARAMETER expressed by lexemes that are considered to be gradable in this language/culture?

-What is the syntactic status of the constitutive elements of the comparative construction/strategy (e.g. core, peripheral arguments)? Are they overtly marked?

-Are any of the elements of the comparative construction/strategy optional? If so, what are factors conditioning their use?

-Does the language allow for the comparison of properties (e.g. He is luckier than he is stupid)?

-What type of clause construction do comparative constructions involve (e.g. copula clause, verbless clause)?

-Which other functions do the grammatical morphemes (STANDARD MARKER, PARAMETER/DEGREE MARKER) used in comparative constructions have elsewhere in the language?

-Is there any indication of the possible diachronic origin of the comparative construction/strategy (e.g. consider calques or borrowings from superstrate languages under language contact or areal diffusion of common patterns)? Is the origin of the grammatical morphemes used in comparative construction/strategy traceable (to e.g. prepositions, adverbs, intensifiers, verbs)?

-Does the language permit attributive comparative constructions? If yes, how are they encoded?

-What types of intensifiers (augmentative, diminutive) are used in the comparative constructions of the language (if any)?

-Are there any inherently comparative lexemes (e.g. [be] better than, [be] taller than)? If so, what word class(es) do they belong to? Do they have any special properties in comparative constructions?

-Are comparative constructions particularly common in certain genres (e.g. language games and contests) and in certain linguistics contexts (e.g. idioms)?

-Which methodologies were applied to collect data for the analysis of comparative constructions (e.g. analysis of a text corpus, elicitation, and non-verbal stimuli)?

Part 2

-Are there any structural similarities between comparative constructions and other comparison constructions?

-How is comparison of equality encoded?

-How is comparison of absolute superiority (superlativity) encoded?

-How is similarity encoded?

-How is identity/equivalence ('the same as') or difference encoded?

-Apply the questions concerning comparative constructions also to other types of comparison constructions.

\section{Contribution to typology of comparative constructions}

Given that there is such a vast amount of literature on comparative constructions, from a typological perspective as well as in the form of descriptions of comparatives in individual languages, how can this special issue still advance our knowledge? First of all, most descriptions assembled in this special issue go beyond a description of comparative constructions in the narrow 
sense and also consider, as far as the data allows, superlative, equative, similative and simulative constructions. This broad approach permits the authors to see structural differences and commonalities between all types of comparison constructions, e.g. which standard markers are shared or have the same etymologies. While the existing typological literature is in large part explicitly concerned with canonical comparison constructions, ${ }^{29}$ which consist of a comparative predicate (parameter) and two noun phrases, one denoting the comparee, the other denoting the standard of comparison, the contributions in this volume do not exclude non-canonical constructions and also examine (i) predicative constructions with complex comparees and standards, (ii) attributive constructions, in which all constitutive elements of a comparison construction are expressed in one noun phrase (Treis, Jacques), (iii) constructions in which two properties are compared (Jacques) and (iv) correlative comparative constructions (van den Berg) and (v) inferiority constructions (Fabre). Inspired by Dixon $(2008,2012)$ some contributions also consider inherently comparative lexemes, which is another little studied feature crosslinguistically (e.g. van den Berg). Wherever possible, authors point out areal marking patterns or contact influence (e.g. Wojtylak) and discuss the diachronic origins of grammatical morphemes used in comparison constructions (e.g. Treis). Finally, the present volume contains the first description of comparative constructions in a sign language (Özsoy \& Kaşıkara).

Several languages described in this volume do not have dedicated comparative constructions with a grammaticalised standard and/or degree marker but use bi-clausal strategies for the expression of comparison (Aikhenvald, Vuillermet, Özsoy \& Kaşıkara). Typological rara that are discussed in the individual papers include, among others, the use of directional verbs in bi-clausal comparatives in Yalaku (Aikhenvald), all-in-one comparatives (one-word comparatives) in Nivacle (Fabre), standards that are incorporated in the parameter in Ese Ejja (Vuillermet) and equative constructions with denominal adjectives ('N-like') in Japhug (Jacques).

With regard to methodology, most descriptions are based on fieldwork corpora collected in the speaker communities and make little use of data collected through translation elicitation. This has several important consequences: Firstly, the descriptions do not concentrate only on primary, frequent comparison constructions but also take many alternative constructions into account (see, for instance, the papers by Fabre, Jacques, van den Berg and Wojtylak; see in this regard also Stolz's (2013) work on competing comparative constructions in Europe and Gorshenin's (2012) work on primary and alternative superlative constructions), some of which are attributable to certain genres (see, for instance, the frequent use of the otherwise rare 'exceed' comparatives in translated Muna material). Secondly, this focus on natural fieldwork data also uncovers problems of data collection that fieldworkers face. As discussed in Tuttle's paper, it may emerge that certain speaker communities do not compare very much and that a description of comparison constructions is then very difficult, and possibly little relevant. Thirdly, the study of the use of comparison constructions in natural contexts may challenge the crosslinguistic validity of established concepts such as gradability and scalarity (Zeisler).

Correlations between linguistic and cultural traits are addressed in the papers by Aikhenvald, Tuttle and van den Berg.

\section{Outline of the volume}

Seven out of eleven papers presented at the workshop "Comparative and Superlative Constructions: Typology and Diachrony" (16-17 June 2015) at the Vrije Universiteit Amsterdam

\footnotetext{
${ }^{29}$ Non-canonical comparison constructions are often explicitly excluded in typological studies, because the consulted sources do not provide data. See, for instance, the comment by Haspelmath et al. (2017: 16f), who recognize the potentially interesting features of attributive equatives but who excluded them from the study due to a lack of data.
} 
are published in this volume, three additional papers have been included to ensure some more geographical and typological variation. As a result, this issue consists of case studies of comparative constructions in languages of the Americas (Murui, Nivacle, Ese Ejja, and Alaskan Athabascan), of Africa (Kambaata), of East and Southeast Asia (Japhug, Ladakh and Muna) and of New Guinea (Yalaku) (see Map 1). It also contains the first ever analysis of comparative constructions in a sign language, Turkish Sign Language.

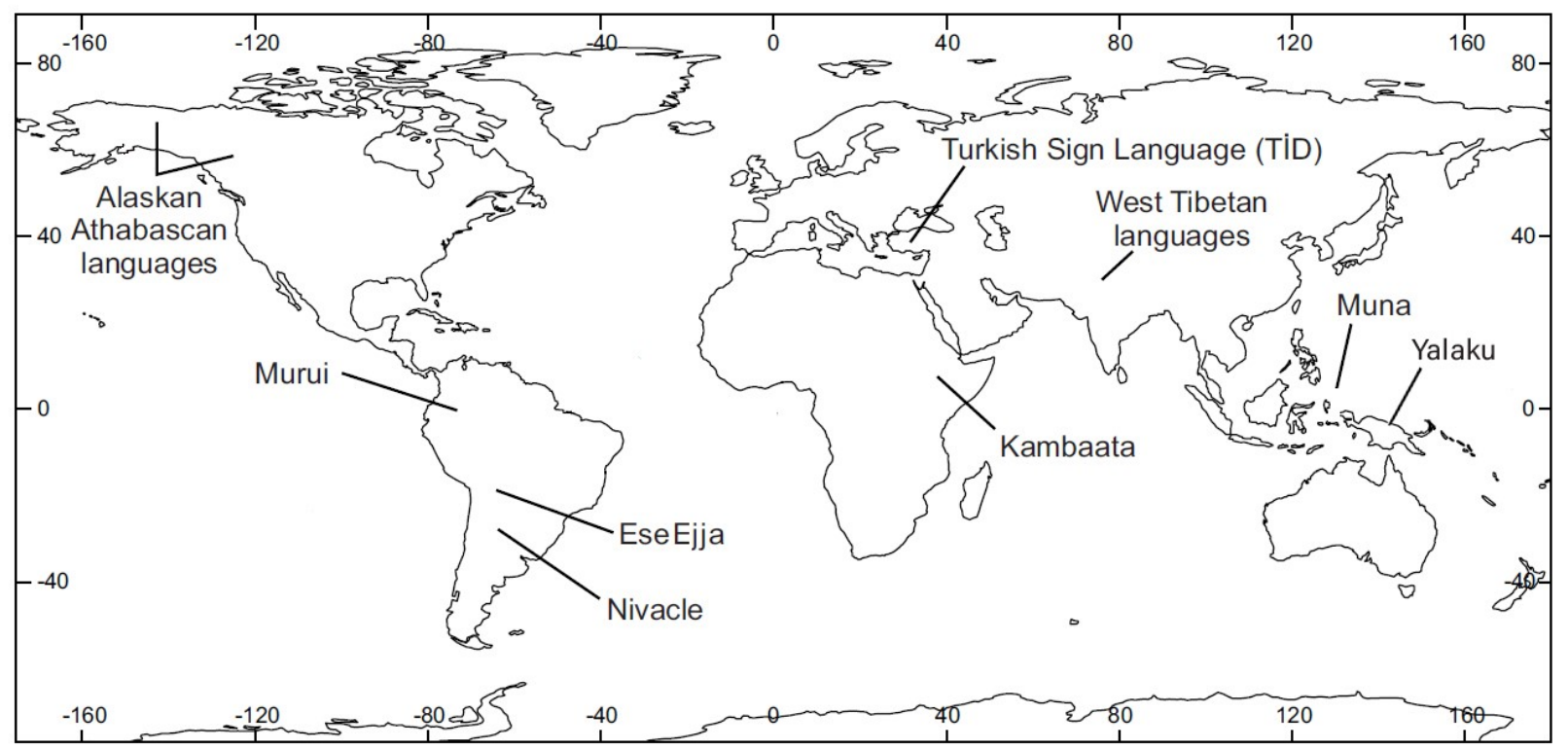

Map 1. Locations of languages included in this volume.

In the first paper, Alexandra Y. Aikhenvald discusses the expression of comparison, contrast and similarity in Yalaku, an Ndu language of Papua New Guinea. Like most Papuan languages, Yalaku does not have a dedicated comparative construction but two uncommon bi-clausal "comparative strategies" in the sense of Dixon (2012: 341-61), each of which involves a contrast. In the first cross-linguistically and areally uncommon strategy, the directional verb 'go up' expresses superiority, while the directional verbs 'go down' and 'go down slope' express inferiority, e.g. 'Child goes down, man goes up, (he) is tall' for 'The child is smaller than the father, (he) is tall'. Secondly, Yalaku employs an areally very common contrastive strategy, in which two antonymous verbless clauses or a positive-negative pair are juxtaposed, e.g. 'I thin, she fat' for 'she is fatter than me' (see also the contributions by Özsoy \& Kaşıkara on Turkish Sign Language, Vuillermet on Ese Ejja). Talking about similarity and equality is shown to be a pervasive feature of Yalaku narratives and conversations. The suffix -meki 'like' expresses similarity, resemblance and related notions. It is attached to different constituents (including relative and co-temporaneous clauses) to mark them as standards of comparison. Equality is expressed only lexically in Yalaku.

Alain Fabre's paper deals with comparative and equative constructions in Nivacle, a language of the Mataguayo family spoken in Paraguay and Argentina. The language is known for its bewildering variety of typological rarities, and comparative and equative constructions show cross-linguistic peculiarities, too. Property concepts in Nivacle are verbs, on which the standard maker is expressed as a verbal suffix and on which both comparee and standard can be personal affixes. This results in cross-linguistically uncommon "all-in-one" comparatives and equatives that are packaged into a single word. Equally noteworthy is the etymology of standard markers in Nivacle: The associated motion suffix $-k^{2} o j a$, which indicates the anticipated coming of a non- 
subject participant in its canonical use, introduces the standard in comparative constructions. The associated motion suffix $-x u$, which indicates the simultaneous coming into the visual field of a non-subject participant in its canonical use, serves to mark the standard of comparison in equative and similative constructions. Fabre gives a detailed overview of a large variety of mono-clausal and bi-clausal construction types and sub-types that Nivacle people use to express inequality, equality, similarity and difference.

Guillaume Jacques's paper on Japhug, a Tibeto-Burman language spoken in the Sichuan province of China, documents a wealth of morpho-syntactically complex equative, similative, comparative and superlative constructions on the basis of a corpus of narratives. In the comparative construction, the standard is marked by a dedicated postposition. For the expression of superlativity, no less than three constructions are attested in Japhug, the first one with a degree marker 'most', the second one with a possessed subject participle ('Y is the $\mathrm{X}$ one of ...'), and the third one with a relative clause with a negative existential verb ('there is no $\mathrm{X}$ one like $\mathrm{Y}$ '). The main similative construction involves an intransitive stative verb 'be like (this)' or a transitive verb 'do like (this)'. The first equative construction is based on the similative construction and uses the verb 'be like (this)'. The second is a complex nominalized degree construction, in which standard and comparee are unified. The third construction leaves the parameter unexpressed and contains a possessed noun 'of the same size'. The fourth equative construction is typological especially interesting because it does not fit any category of existing equative typologies; it is built on denominal adjectives ('N-like'). Despite the lexical influence of Tibetan languages on Japhug and the fact that some of the comparison constructions involve Tibetan borrowings, none of them appears to be calqued from their Tibetan equivalents.

A. Sumru Özsoy \& Hüner Kaşıkara show that Turkish Sign Language has two distinct comparative constructions, namely conjoined comparatives and locational comparatives. Conjoined comparatives are made up of two independent clauses; one clause contains the standard NP, the other one the comparee NP, both occur in subject function in their clauses. In locational comparative constructions, a single predicate expresses the parameter shared by the participants. The two NPs are located in the signing space by indexing (IX) and body shift. Comparison between the two arguments is encoded by IX one of the means that sign languages use to represent the relationship between verbs and their arguments and that the direction of the path movement of the manual sign is determined by the thematic roles of the arguments from the R-locus of the SOURCE argument to the R-locus of the GOAL argument in "backward agreement" contexts, the authors argue that the directionality of movement in the comparative construction in Turkish Sign Language is parallel to the verbal agreement of sign languages.

Yvonne Treis's paper is an in-depth study of the expression of comparison in Kambaata, a Highland East Cushitic language of Ethiopia. It discusses not only quantitative comparison, i.e. comparison of relative and absolute inequality and comparison of equality, but also analyses the morphology and syntax of expressions of qualitative comparison, i.e. comparison of similarity. Apart from canonical predicative constructions, the analysis also takes attributive constructions into account. In the comparative construction (lit. ' $\mathrm{X}$ is tall from $\mathrm{Y}$ '), the standard of comparison is marked by the ablative case, as in most languages spoken in the Horn of Africa. Kambaata distinguishes between two superlative constructions, one of which is based on the comparative construction (' $\mathrm{X}$ is tall from all'), while the other is characterised by a locative standard of comparison (' $\mathrm{X}$ is tall among $\mathrm{Y}$ '). Furthermore, Kambaata has two equative constructions. The first is based on the similative construction (' $\mathrm{X}$ is tall like $\mathrm{Y}$ '); the second is a periphrastic construction (' $\mathrm{X}$ is tall to the extent $\mathrm{Y}$ '). The paper argues that the enclitic morpheme which marks 
the standard of comparison in the similative construction originates from a noun meaning 'manner'.

Siri Tuttle surveys comparative constructions in three Alaskan Athabascan languages, Koyukon, Ahtna and Tanana based on archived and published examples and fieldwork experiments. Comparatives in these languages fall into Dixon's $(2008,2012)$ Type A2, with parameters being expressed through adjectival neuter verbs and standard markers in (spatial/temporal) postpositions. Superlatives are not as well represented in lexical documentation as comparatives, which are themselves rare in texts. In order to supplement her database, the author resorts to the elicitation of expressions of comparison, assisted by non-verbal stimuli. The results of her experiments in Ahtna and Koyukon support her earlier observations that the rarity of comparatives and superlatives is related to cultural norms in Athabascan communities, where comparison (especially of people) can be considered rude, and superlatives evidence of inappropriate pride.

René van den Berg's contribution takes us to Sulawesi (Indonesia), where he studies the expression of comparison in the Austronesian language Muna. The authors addresses a variety of comparative, superlative and equative constructions and embeds their description in the typological discussion. Of typological interest in Muna comparative constructions are the use of a comitative preposition as standard marker (lit. 'he big-s with me' for 'he is bigger than me') and the lack of a designated lexeme 'less' for the expression of inferior degree. While 'surpass' comparatives are an infrequent alternative to the regular comparative with 'with', a participial form of 'surpass' serves regularly as the degree marker in superlative constructions. In the most common equative construction, the degree is expressed by an intransitive verb 'be the same' followed by a nominalized stative verb expressing the parameter of comparison. One section of van den Berg's paper is specifically dedicated to Muna correlative comparison constructions, in which two comparative clauses are juxtaposed and introduced by the same conjunction ('the more'). In an excursus at the end of his paper, van den Berg relates the wealth of comparison constructions to various aspects of Muna culture such as the popularity of competitive games and the traditional social stratification.

Marine Vuillermet examines the expression of comparison in the Amazonian language Ese Ejja (Takanan) and explores both quantitative (relative (in)equality and superlativity) and qualitative comparison (similarity and simulation). This broad perspective reveals a clear asymmetry: while qualitative comparison is expressed via morphemes well incorporated into the grammar of the language, i.e. dedicated suffixes and enclitics, and is well represented in the corpus, quantitative comparison is most often expressed by strategies (rather than dedicated morphology) and is scarce in her corpus of spontaneous language. The quasi-absence of dedicated morphology for the expression of quantitative comparison is all the more remarkable when taking into account that the language has a large class of adjectives with a rich paradigm of adjectival affixes, which, for instance, negate, attenuate or question the adjectival root. Comparison of relative inequality is expressed by the juxtaposition of antonymous clauses, positive-negative pairs or positive-'slightly' pairs.

Katarzyna Wojtylak analyses the forms and functions of different types of mono- and biclausal comparative constructions in Murui, an endangered Witotoan language of north-western Amazonia (Colombia, Peru). The most common comparative constructions are characterised by five different standard markers that originate in adverbs and demonstratives expressing distance, containment, and position in the vertical space. The semantics of the standard markers allow a division between two parallel types of comparative constructions, those that express superiority ('ahead', 'outside', 'high'), and those that convey inferiority ('inside', 'low'). Wojtylak shows that Murui comparative constructions are undergoing change under the strong influence of Spanish. 
While Murui elders still make use of a variety of standard markers, younger speakers tend to restrict themselves to 'ahead' for a higher degree and 'inside' for a lower degree. Furthermore, new comparative constructions and comparative strategies are on the rise, by means of analogy with the Spanish preposition de 'of, from, about'. The last sections of Wojtylak's paper are dedicated to the expression of equality and similarity. In Murui mono-clausal equative constructions the standard of comparison is marked by an independent postposition 'similar'. In addition, Murui possesses an equal size morpheme $-z e$, which is suffixed to nouns to derive forms meaning 'as big/small as N'.

Based on an extensive corpus of data from a variety of sources collected during long periods of fieldwork, Bettina Zeisler argues in her paper that West Tibetan differentiating property ascriptions (what other authors would call "comparative constructions") might be best understood as categorical relations of difference rather than comparisons imply a scale. In the literature on comparison, non-equative comparison is typically interpreted in terms of degree semantics. That is, the comparee is thought to have the same property as the standard, but to a different degree. However, Zeisler introduces a different way of conceptualising differences, namely categorical contrasting, where one focuses more on the contrast than on the gradualness of the difference. Two items are described as being essentially different with respect to a certain property, and this can imply that the standard against which an item is contrasted lacks the property in question. In order to show that this approach is more suitable for the West Tibetan varieties spoken in Ladakh, Zeisler does not only discuss the standard ways of expressing differences, but also some more marginal constructions at the limit of acceptability.

\section{Acknowledgements}

I gratefully acknowledges funding from the federation Typologie et Universaux Linguistiques (FR2559) of the French National Centre for Scientific Research (CNRS) for the project Expression des comparaisons d'égalité et de similitude (2014-2018). I am thankful to Kasia Wojtylak for her comments and discussions on the previous versions of this paper. Thanks also go to Brigitta Flick for proof-reading the entire volume.

\section{References}

Aikhenvald, Alexandra Y. this volume. Comparison, contrast and similarity in Yalaku.

Andersen, Paul Kent 1983. Word Order Typology and Comparative Constructions. Amsterdam: John Benjamins.

Bobaljik, Jonathan David 2012. Universals in Comparative Morphology: Suppletion, Superlatives, and the Structures of Words. Cambridge, MA: MIT Press.

Chamoreau, Claudine 2012. Contact-induced changes as an innovation. In: Chamoreau, Claudine \& Isabelle Léglise (eds.). Dynamics of Contact-Induced Language Change, pp. 53-76. Berlin: De Gruyter Mouton.

Coppock, Elizabeth 2016. Typological database of superlative constructions, doi:10.7910/DVN/71WHWY, Harvard Dataverse, V3.

Cuzzolin, Pierluigi \& Christian Lehmann 2004. Comparison and gradation. In: Booij, Geert, Christian Lehmann, Joachim Mugdan \& Stavros Skopeteas (eds.). Morphologie. Ein internationales Handbuch zur Flexion und Wortbildung, vol. 17.2, pp. 1857-1882. Berlin, New York: W. de Gruyter. 
de Reuse, Willem J. 1994. Siberian Yupik Eskimo. The Language and its Contacts with Chukchi. Salt Lake City, UT: University of Utah Press.

Dixon, R.M.W. 2008. Comparative constructions: A cross-linguistic typology. Studies in Language 32, 4: 787-817.

Dixon, R.M.W. 2012. Basic Linguistic Theory. Volume 3. Further Grammatical Topics. Oxford: Oxford University Press.

Fabre, Alain this volume. Some peculiarities of comparative constructions in Nivacle (Mataguayo family, Paraguayan Chaco).

Fuchs, Catherine 2014. La comparaison et son expression en français. Paris: Ophrys.

Greenberg, Joseph H. 1966. Some universals of grammar with particular reference to the order of meaningful elements. In: Greenberg, Joseph H. (ed.). Universals of Language, pp. 73-113. $2^{\text {nd }}$ ed. Cambridge, MA: MIT Press.

Gorshenin, Maksym 2012. The crosslinguistics of the superlative. In: Stroh, Cornelia (ed.). Neues aus der Bremer Linguistikwerkstatt: Aktuelle Themen und Projekte 31, pp. 55-160. Bochum: Brockmeyer.

Haspelmath, Martin \& Oda Buchholz. 1998. Equative and similative constructions in the languages of Europe. In: Van der Auwera, Johan (ed.), Adverbial Constructions in the Languages of Europe, pp. 277-334. Berlin: Mouton de Gruyter.

Haspelmath, Martin and the Leipzig Equative Constructions Team 2017. Equative constructions in world-wide perspective. In: Treis, Yvonne \& Martine Vanhove (eds.). Similative and Equative Constructions: A Cross-linguistic Perspective, pp. 9-32. Amsterdam, Philadelphia: John Benjamins.

Heine, Bernd 1994. Areal influence on grammaticalisation. In: Pütz, Martin (ed.). Language Contact and Language Conflict, pp. 55-68. Amsterdam: John Benjamins.

Heine, Bernd 1997. Cognitive Foundations of Grammar. Oxford: Oxford University Press.

Heine, Bernd \& Zelealem Leyew 2003. Comparative constructions in Africa: An areal dimension. Annual Publication in African Linguistics 1: 47-68.

Henkelmann, Peter 2006. Constructions of equative comparison. Sprachtypologie und Universalienforschung 59, 4: 370-398.

Jacques, Guillaume 2016. From ergative to comparee marker: Multiple reanalyses and polyfunctionality. Diachronica 33, 1: 1-30.

Jacques, Guillaume this volume. Similative and equative constructions in Japhug.

Jensen, Hans 1934. Der steigernde Vergleich und sein sprachlicher Ausdruck. Indogermanische Forschungen 52: 108-130.

Olawsky, Knut 2006. A Grammar of Urarina. (Mouton Grammar Library, 37.) Berlin: Mouton de Gruyter.

Özsoy, A. Sumru \& Hüner Kaşıkara this volume. Comparatives in Turkish Sign Language (TID).

Rust, Friedrich 1965. Praktische Namagrammatik: Auf Grund der Grammatiken von H. Vedder und J. Olpp (The School of African Studies University of Cape Town, 31.). Cape Town: A.A. Balkema.

Saltarelli, Mario 1988. Basque. (Croom Helm Descriptive Grammars) London, New York: Routledge.

Schulze, Wolfgang 2017. Toward a cognitive typology of like-expressions. In: Treis, Yvonne \& Martine Vanhove (eds.). Similative and Equative Constructions: A Cross-linguistic Perspective, pp. 33-77. Amsterdam, Philadelphia: John Benjamins.

Stassen, Leon 1985. Comparison and Universal Grammar. Oxford: Basil Blackwell. 
Stassen, Leon 2013. Comparative constructions. In: Dryer, Matthew S. \& Martin Haspelmath (eds.). The World Atlas of Language Structures Online. Leipzig: Max Planck Institute for Evolutionary Anthropology. Available online at: http://wals.info/chapter/121

Stolz, Christel \& Thomas Stolz 1995. Spanisch-amerindischer Sprachkontakt: Die 'Hispanisierung' mesoamerikanischer Komparationsstrukturen. Iberoamerica 58/59, 2/3: 5-42.

Stolz, Christel \& Thomas Stolz 2001. Hispanicised comparative constructions in indigenous languages of Austronesia and the Americas. In: Zimmermann, Klaus \& Thomas Stolz (eds.). Lo propio y lo ajeno en las lenguas austronésicas y amerindias. Procesos interculturales en el contacto de lenguas indígenas con el español en el Pacifico e Hispanoamérica, pp. 35-56. Frankfurt: Vervuert.

Stolz, Thomas 2013. Competing Comparative Constructions in Europe. Berlin: Akademie-Verlag.

Treis, Yvonne this volume. Comparison in Kambaata: Superiority, equality and similarity.

Treis, Yvonne \& Martine Vanhove (eds.) 2017. Similative and Equative Constructions: A Crosslinguistic Perspective. (Typological Studies in Language, 117.) Amsterdam, Philadelphia: John Benjamins.

Tuttle, Siri G. this volume. Comparative and superlative constructions in Alaskan Athabascan languages.

Ultan, Russell 1972. Some features of basic comparative constructions. Working Papers on Language Universals (Stanford) 9: 117-162.

van den Berg, René this volume. More than most: comparative constructions in Muna (Sulawesi, Indonesia).

Vuillermet, Marine this volume. Comparative, similative and simulative expressions in Ese Ejja.

Wojtylak, Katarzyna I. this volume. Comparative constructions in Murui (Witotoan, Northwest Amazonia).

Zeisler, Bettina this volume. Contrast instead of comparison: Evidence from West Tibetan differentiating property ascriptions.

Ziemer, Hermann 1884. Vergleichende Syntax der indogermanischen Comparation insbesondere der Comparationscasus der indogermanischen Sprachen und sein Ersatz. Berlin: Dümmler. 